\title{
THE MEPHISTO BEST-PUBLICATION AWARD
}

\author{
The Board of ICCA
}

The Mephisto Best-Publication Award, for the first time announced in the June/September 1988 issue of the ICCA Journal, has been presented annually to authors of a publication which, in the opinion of the jury, has made the biggest contribution to computer chess in the year in question. The first Award was for publications dated between April 1 ${ }^{\text {st }}, 1987$ and March 31 ${ }^{\text {st }}, 1988$ (and won by Thomas Anantharaman, Murray Campbell and Feng-hsiung Hsu for their paper: 'Singular Extensions: Adding Selectivity to Brute-Force Searching' published in Proceedings of the AAAI Spring Symposium, Computer Game Playing, March 1988), the second Award for publications dated between April $1^{\text {st }}, 1988$ and March $31^{\text {st }}, 1989$ (adjudged to the book Advances in Computer Chess 5, edited by Don Beal), the third for publications dated between April $1^{\text {st }}, 1989$ and March $31^{\text {st }}, 1990$ (awarded to Feng-hsiung Hsu for his Ph.D. thesis, entitled Large Scale Parallelization of Alpha-Beta Search: An Algorithmic and Architectural Study with Computer Chess), and the fourth for publications between April $1^{\text {st }}, 1990$ and March 31 ${ }^{\text {st }}, 1991$ (awarded to Tony and Linda Scherzer and Dean Tjaden for their article 'Learning in Bebe', published in Computers, Chess, and Cognition, edited by T.A. Marsland and J. Schaeffer, pp. 197-216).

The fifth Mephisto Best-Publication Award for publications between April $1^{\text {st }}, 1991$ and March $31^{\text {st }}, 1992$ is shared between Thomas Anantharaman for his article 'Extension Heuristics', ICCA Journal, Vol. 14, No. 2, pp. 47-63, and Jos Uiterwijk for his article 'The Countermove Heuristic', ICCA Journal, Vol. 15, No. 1, pp. 8-15.

The jury consisted of Don Beal, Robert Hyatt, David Levy, Tony Marsland, Tony Scherzer and Ken Thompson.

The ICCA would once again like to thank Hegener + Glaser AG of Munich, for donating this award and the jury for their labours.

Since Hegener + Glaser AG have generously renewed their sponsorship of this award (see below), we announce the continuation to a 1992-1993 Mephisto Best-Publication Award, qualification dates for which are from April $1^{\text {st }}, 1992$, to March $31^{\text {st }}, 1993$, including the June, September and December 1992 issues of the ICCA Journal, as well as the March 1993 issue. Once again, any publication on or related to computer chess will be considered, and the Award is not limited to papers presented in the ICCA Journal.

\section{ICCA AWARDS, OLD AND NEW}

\author{
The Board of ICCA
}

The Board of ICCA has the pleasure to inform you about three Awards, two of which are new.

1. Hegener + Glaser AG have been donating the "Mephisto Best-Publication Award" for the past 5 years, which was the period originally agreed between the company and the ICCA. We are delighted to announce that Hegener + Glaser AG have now consented to continue the award for a further two years. Moreover, they have an option to extend that period for a further two years thereafter.

2. The ICCA has instituted a new award, to be adjudged to the best author new to computer chess, for an article in the ICCA Journal. The first award covers articles published in four consecutive issues of the Journal, starting from Vol. 15, No. 2 (June 1992) up to and including Vol. 16, No. 1 (March 1993). The winner will receive a hand-lettered certificate to this effect and will have a choice of three Volumes of the Journal's back issues. The name of the winning author will also, of course, be published in the ICCA Journal with a short curriculum vitae if so desired and an abbreviated version of the jury's report, giving reasons for their choice. 